\title{
EFFECTS OF ORGANIC AND INORGANIC NITROGEN ON GROWTH, YIELD AND QUALITY OF SAPOTA 'KALIPATTI'
}

\author{
Varu Devashi \\ Department of Horticulture, Junagadh Agril \\ University Junagadh-362 001, Gujarat INDIA \\ e-mail:dkvaru@yahoo.com
}

(Received February 17, 2012/Accepted May 15, 2012)

\section{A B S T R A C T}

An experiment was conducted to study the effect of organic and inorganic nitrogen in the form of urea and castor cake on the growth, yielding and fruit quality of sapota trees. Nitrogen in the form of urea significantly influenced the vegetative growth of the trees. The greatest tree height $(7.26 \mathrm{~m})$, tree spread $(8.11 \mathrm{~m}$ in N-S and $8.13 \mathrm{~m}$ in $\mathrm{E}-\mathrm{W}$ directions), fruit weight $(63.65 \mathrm{~g})$, the number of fruit per tree (2627.56) and fruit yield per tree $(163.30 \mathrm{~kg})$ were obtained with the application of $900 \mathrm{~g} \mathrm{~N} /$ tree in the form of urea. However, that was found on a par with the application of $900 \mathrm{~g} \mathrm{~N} /$ tree in which $50 \% \mathrm{~N}$ was from urea and $50 \%$ from castor cake. Total sugars and reducing sugars content in fruit was found the highest in the $900 \mathrm{~g} \mathrm{~N} /$ tree treatment in which $25 \% \mathrm{~N}$ was from urea and $75 \% \mathrm{~N}$ from castor cake.

Key words: fertilization, urea, nitrogen, castor cake

\section{INTRODUCTION}

Sapota or sapodilla (Manilkara achras), popularly known as chiku, is one of the important tropical fruit crops of India. This species is native to tropical America, especially southern Mexico and Central America. The fruit is a fleshy berry, variable in shape, size and weight (75-150 g). The skin is thin, rusty brown, somewhat scurfy, looking like the Irish potato, and the pulp soft, melting and crumbling with a sandy or granular texture, with 1-5 hard, black seeds. The fruit is a good source of digestible sugar (12-18\%) and an appreciable source of protein, fat, fibre and minerals ( $\mathrm{Ca}, \mathrm{P}$ and $\mathrm{Fe}$ ). The area under this crop plant is increasing due to its high productivity, continuous fruiting throughout the year and very little 
incidence of pests and diseases. It is cultivated on 160000 hectares with a total production of 1424000 tones in India. It has become the most popular fruit crop in Gujarat, Maharashtra, and Karnataka, and so these are the major sapota producing states in India. It is also produced to some extent in Andhra Pradesh, West Bengal, Orissa and Tamil Nadu. The productivity is more or less the same in all the states, except that it is very high in Tamil Nadu and very low in Orissa.

Sapota is a hardy crop and can tolerate salinity to some extent (Sulladmath and Reddy, 2001). Chemical fertilizers are commonly used because they can ensure quick availability of the nutrients to the plants. However, continuous application of inorganic fertilizers deteriorates the soil's health (Warade et al., 1995). Therefore, chemical fertilizers must be integrated with sources of organic manure which are eco-friendly for sustaining productivity without deteriorating effects on soil health and the environment. The yield can be increased or sustained, but the quality is improved through the balanced application of organic and inorganic fertilizers. The information on the effect of nitrogen in sources such as urea and castor cake on the growth, yielding and fruit quality of sapota trees is scanty. The castor cake comes from the castor plant (Ricinus communis), and is the solid residue obtained when castor seeds are crushed during the expression of castor bean oil. The solvent-extracted cake, although rich in protein, cannot be used as cattle fodder because of its toxicity. However, it can be used as a fertilizer. It is one of the most versatile natural manures. It is truly organic manure which enhances the fertility of the soil without causing any damage or decay. It is enriched with the three major elements vital and conducive to the proper growth of crops - nitrogen, phosphorus and potassium. It also contains trace nutrients like manganese, zinc and copper, thus making it a balanced fertilizer. Moreover, it helps to neutralize the detrimental effects of chemical fertilizers.

Keeping the above facts in view, the present investigation was undertaken to find out the optimum dose and best combination of inorganic fertilizers and organic manure for obtaining higher growth, yield and quality of sapota 'Kalipatti'.

\section{MATERIAL AND METHODS}

The study was carried out to examine the effect of organic and inorganic nitrogen fertilization, in the form of castor cake along with urea, on the growth, yielding and fruit quality of sapota trees 'Kalipatti'. The experiment was conducted at the Department of Horticulture, College of Agriculture, Junagadh Agricultural University, Junagadh (Gujarat) over three years (2006 to 2008). Fifteen-year-old plants were used for the experiment. There were 9 treatments and the details of the treatments are given in Table 1.

The experiment was laid out in a randomized block design with 3 replicates per treatment ( 3 trees per replicate). The soil of the experimental 
Table 1. Doses and forms of nitrogen supplied to sapota trees

\begin{tabular}{|l|l|}
\hline Treatment & \multicolumn{1}{c|}{$\begin{array}{c}\text { Treatment details } \\
\text { Dose and form of nitrogen [per tree per year] }\end{array}$} \\
\hline $\mathrm{T}_{1}$ & $1200 \mathrm{~g}$ nitrogen from urea \\
\hline $\mathrm{T}_{2}$ & $1200 \mathrm{~g}$ nitrogen $-50 \% \mathrm{~N}$ from urea and $50 \% \mathrm{~N}$ from castor cake \\
\hline $\mathrm{T}_{3}$ & $1200 \mathrm{~g}$ nitrogen $-25 \% \mathrm{~N}$ from urea and $75 \% \mathrm{~N}$ from castor cake \\
\hline $\mathrm{T}_{4}$ & $900 \mathrm{~g}$ nitrogen from urea \\
\hline $\mathrm{T}_{5}$ & $900 \mathrm{~g}$ nitrogen $-50 \% \mathrm{~N}$ from urea and $50 \% \mathrm{~N}$ from castor cake \\
\hline $\mathrm{T}_{6}$ & $900 \mathrm{~g}$ nitrogen $-25 \% \mathrm{~N}$ from urea and $75 \% \mathrm{~N}$ from castor cake \\
\hline $\mathrm{T}_{7}$ & $750 \mathrm{~g}$ nitrogen from urea \\
\hline $\mathrm{T}_{8}$ & $750 \mathrm{~g}$ nitrogen $-50 \% \mathrm{~N}$ from urea and $50 \% \mathrm{~N}$ from castor cake \\
\hline $\mathrm{T}_{9}$ & $750 \mathrm{~g}$ nitrogen $-25 \% \mathrm{~N}$ from urea and $75 \% \mathrm{~N}$ from castor cake \\
\hline
\end{tabular}

site was medium black with good drainage capacity, having EC $0.15 \mathrm{mS} \mathrm{cm}^{-1}, \mathrm{pH}-8.1$, organic carbon $-0.72 \%$, available $\mathrm{P}-24.61 \mathrm{mg}$ $\mathrm{kg}^{-1}$, and $\mathrm{K}-175 \mathrm{mg} \mathrm{kg}^{-1}$. Chemical fertilizers, like $\mathrm{P}_{2} \mathrm{O}_{5}$ and $\mathrm{K}_{2} \mathrm{O}$, were applied at $450 \mathrm{~g}$ per tree as the basal dose. Nitrogen in the form of urea and castor cake was applied in two equal splits, i.e. castor cake as the basal dose and urea in top dressing in June and October, respectively. At the time of application of fertilizers, a trench of $30 \mathrm{~cm}$ width and depth, $1 \mathrm{~m}$ away from trunk of the tree was prepared. All the fertilizers were applied in trench and covered with the soil.

The tree height and tree spread $(\mathrm{N}-$ $\mathrm{S}$ and E-W directions) were recorded as vegetative growth parameters. In the case of yield and yield attributes, fruit length and girth, fruit weight, the number of fruit per tree and fruit yield were recorded. The quality parameters such as the total and reducing sugars content were measured post-harvest in a labo- ratory with titration method (Dubois et al., 1956; Hodge and Hofreiter, 1962). The total soluble solids content (TSS) was determined using a hand refractometer. Data were analyzed using analysis of variance as described by Panse and Sukhatme (1985).

\section{RESULTS AND DISCUSSION}

\section{Growth parameters}

The data presented in Table 2 indicate that there were significant differences in plant growth parameters. The greatest tree height $(7.26 \mathrm{~m})$ and tree spread $(8.11 \mathrm{~m}$ in $\mathrm{N}-\mathrm{S}$ and $8.13 \mathrm{~m}$ in $\mathrm{E}-\mathrm{W}$ directions) were recorded for the application of $900 \mathrm{~g}$ $\mathrm{N} /$ tree in the form of urea $\left(\mathrm{T}_{4}\right)$, but that was found to be on a par with the $900 \mathrm{~g} \mathrm{~N} /$ tree treatment in which $50 \%$ of nitrogen was from urea and $50 \%$ from castor cake $\left(\mathrm{T}_{5}\right)$. The lowest tree height was noted for the application of $900 \mathrm{~g} \mathrm{~N} /$ tree in which $75 \% \mathrm{~N}$ was from castor cake and $25 \%$ from urea $\left(\mathrm{T}_{6}\right)$. The greatest tree 


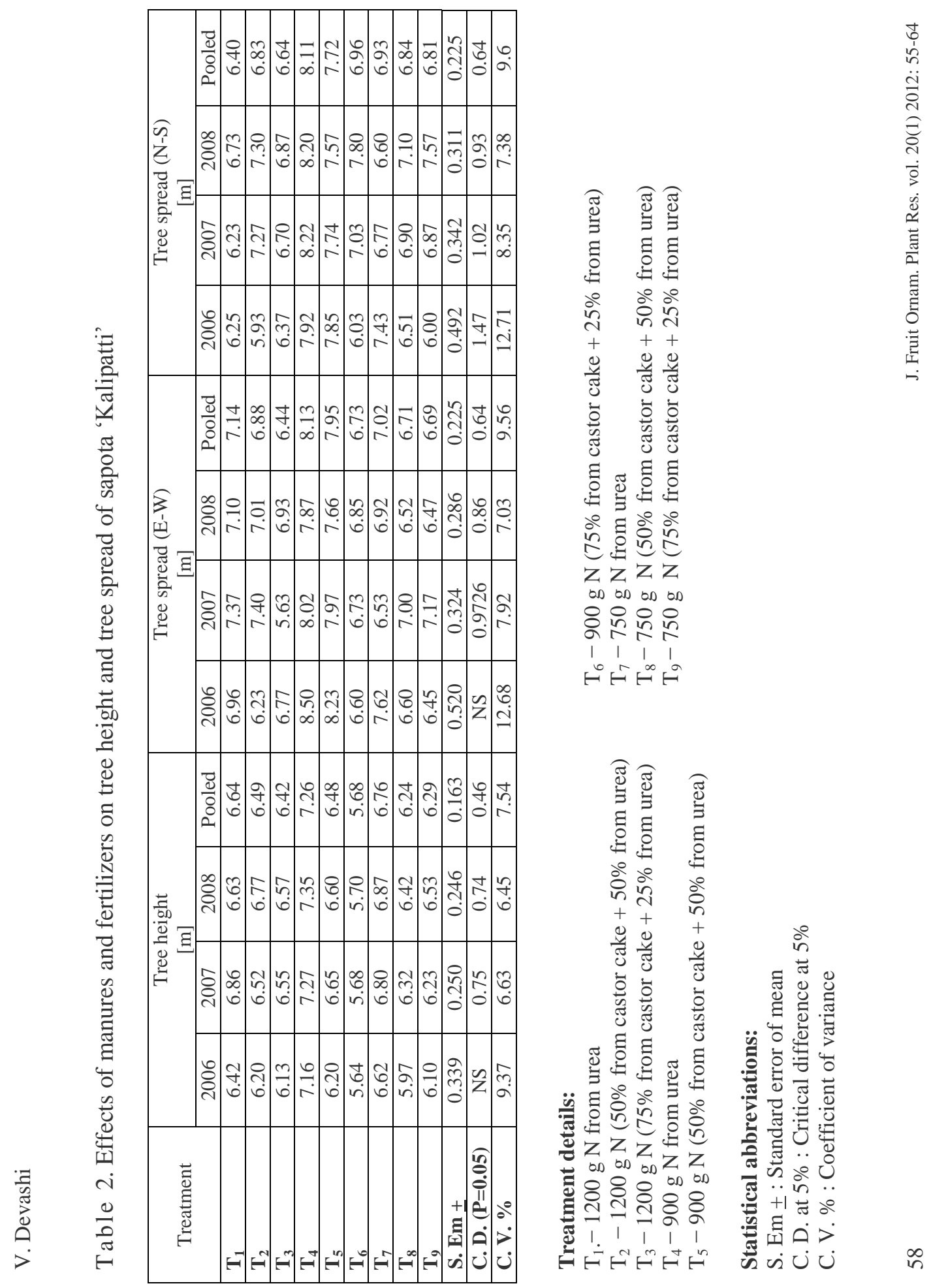


height and tree spread may be due to the easy and ready availability of nitrogen from urea. On the other hand, the poor result obtained in the combination in which $75 \%$ of nitrogen was from castor cake $\left(\mathrm{T}_{6}\right)$ may be due to a low and slow availability of nitrogen to the plants.

\section{Yield and yield attributes}

Significant variations in fruit weight, the number of fruit per tree and fruit yield due to different sources of nitrogen were observed (Tab. 3). The highest fruit weight $(63.65 \mathrm{~g})$, the largest number of fruit per tree (2627.56) and the highest fruit yield $(163.30 \mathrm{~kg})$ were recorded in the combination in which $900 \mathrm{~g}$ $\mathrm{N} /$ tree was applied in the form of urea $\left(\mathrm{T}_{4}\right)$. However, that was found on a par with the application of $900 \mathrm{~g}$ $\mathrm{N} /$ tree in which $50 \% \mathrm{~N}$ was from urea and $50 \% \mathrm{~N}$ from castor cake $\left(\mathrm{T}_{5}\right)$. The lowest fruit weight $(42.97 \mathrm{~g})$ and fruit yield per tree $(109.18 \mathrm{~kg})$ were obtained with the dose of $750 \mathrm{~g} \mathrm{~N} /$ tree in which $50 \% \mathrm{~N}$ was from castor cake and $50 \%$ from urea $\left(\mathrm{T}_{8}\right)$. The smallest number of fruit per tree (2038) was obtained with $750 \mathrm{~g} \mathrm{~N} /$ tree $(75 \% \mathrm{~N}$ from castor cake and $25 \%$ from urea $-\mathrm{T}_{9}$ ). The highest yield and the largest number of fruit per tree were recorded at $900 \mathrm{~g} \mathrm{~N}$ instead of $1200 \mathrm{~g}$ $\mathrm{N}$ because $900 \mathrm{~g} \mathrm{~N}$ might be the optimum dose for sapota trees compared to the higher dose of nitrogen which might have created an imbalance of nutrients. The higher yield might have been due to a ready availability of nitrogen from urea, which increased tree growth and ultimately improved the yield.

Significantly higher fruit length and fruit girth $(5.21$ and $4.80 \mathrm{~cm}$, respectively) were obtained with the application of $900 \mathrm{~g} \mathrm{~N} /$ tree in which $50 \% \mathrm{~N}$ was from urea and $50 \% \mathrm{~N}$ from castor cake $\left(\mathrm{T}_{5}\right)$ (Tab. 4). The lowest fruit length was observed in the combination in which $750 \mathrm{~g}$ $\mathrm{N} /$ tree was applied in the form of urea $\left(T_{7}\right)$. The lowest fruit girth was obtained with the $750 \mathrm{~g} \mathrm{~N} /$ tree treatment in which $50 \% \mathrm{~N}$ was from urea and $50 \%$ form castor cake $\left(\mathrm{T}_{8}\right)$.

The poor yield obtained in the combination with the lowest dose of nitrogen (with $50 \%$ of $\mathrm{N}$ form castor cake) was most likely due to a lower and slower availability of nitrogen. Similarly, Singh et al. (2000) observed that the number of fruit per tree increased with the application of higher levels of nitrogen. The result was also in conformity with the finding of Bhuva et al. (1990), Boora and Singh (2000), Durrani et al. (1982ab), Boora et al. (2002), and Singh et al. (2003).

\section{Quality parameters}

The highest reducing sugars and total sugars content (5.02 and 7.10\%, respectively) were obtained in the treatment with $900 \mathrm{~g} \mathrm{~N} /$ tree in which $25 \% \mathrm{~N}$ was from urea and $75 \% \mathrm{~N}$ from castor cake $\left(\mathrm{T}_{6}\right)$ (Tab. 5). The highest total soluble solids content (TSS $-18.59{ }^{\circ}$ Brix) was obtained in treatment $\mathrm{T}_{5}$, but that was on a par with treatments $T_{2}, T_{3}, T_{4}$ and $T_{6}$. The qualitative parameters such as the reducing and total sugar content and TSS were improved with the 


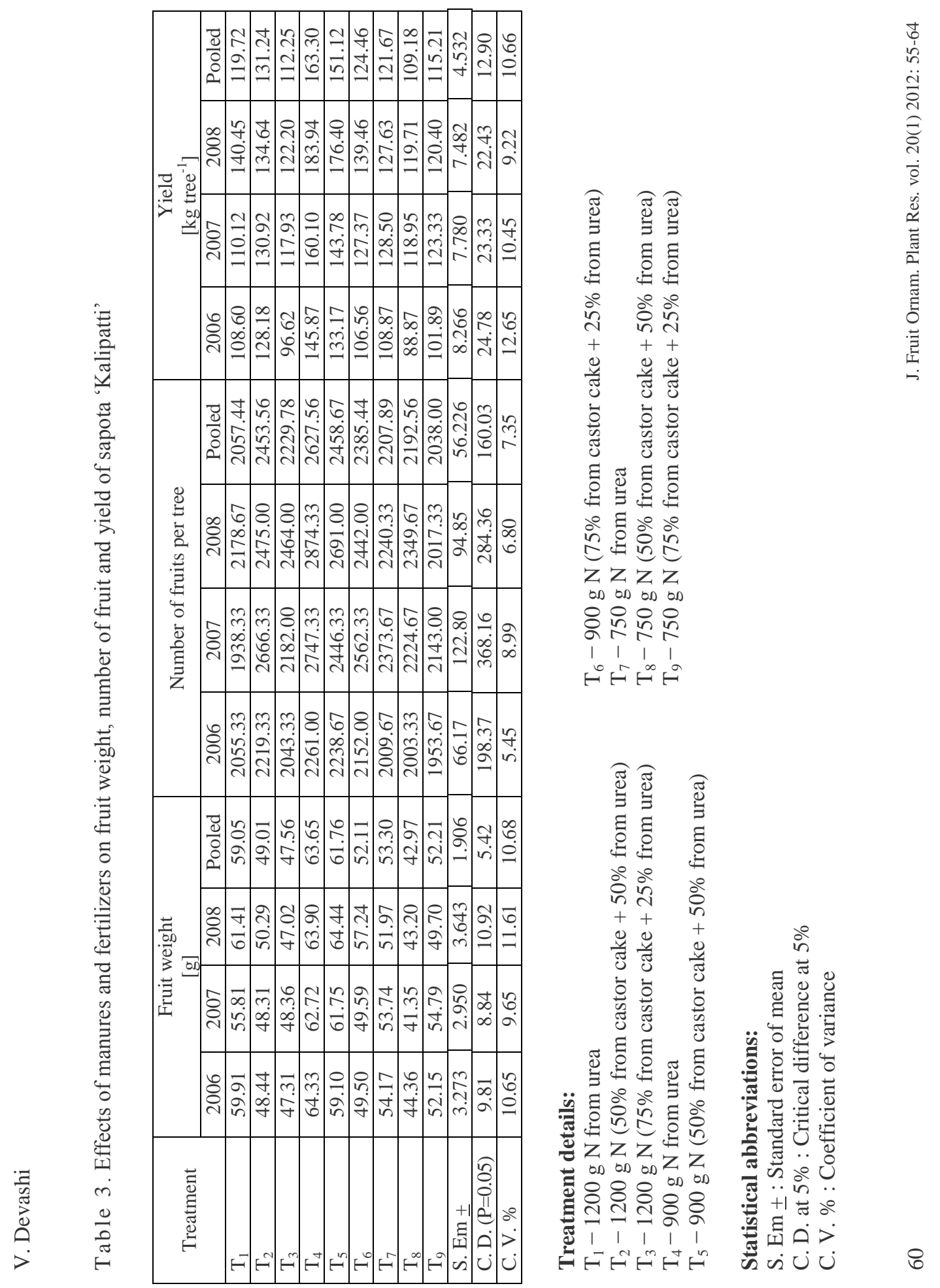




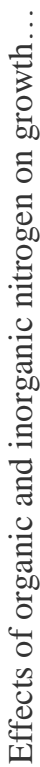

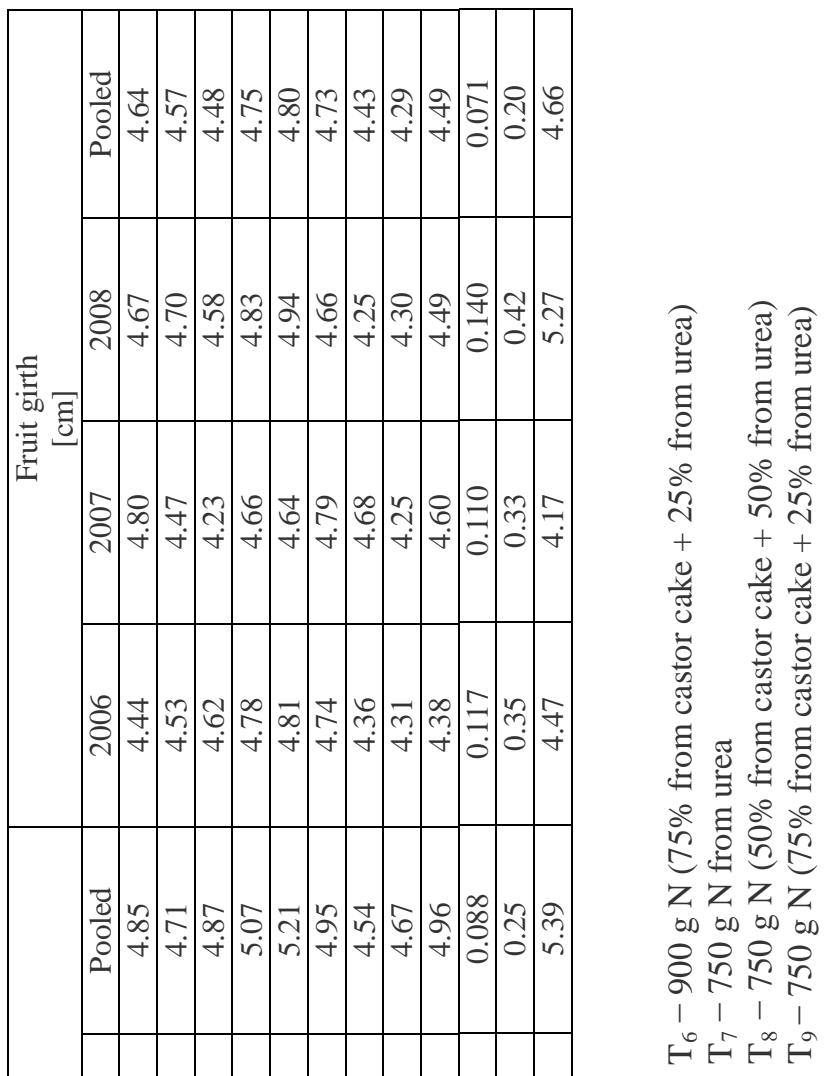

先

要

政

.

Tृ

흠

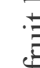

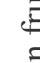

(5)

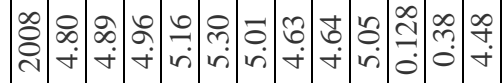

동

를

혼

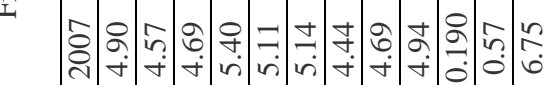

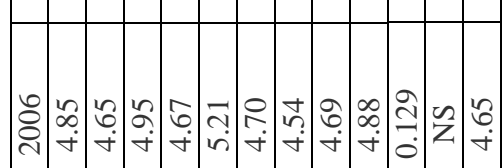

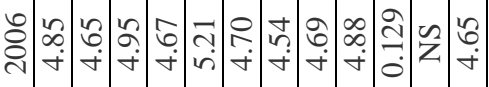

กิ

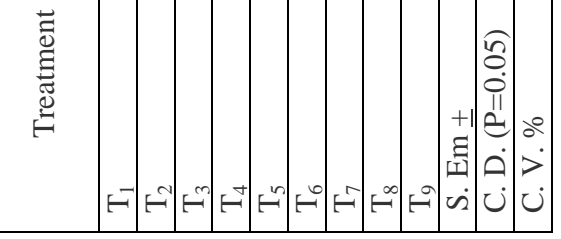

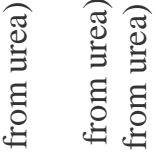

年光

$+\quad+$

莽

泀

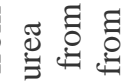

o z do

은

乙 Z Z Z

응윤윤은

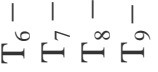

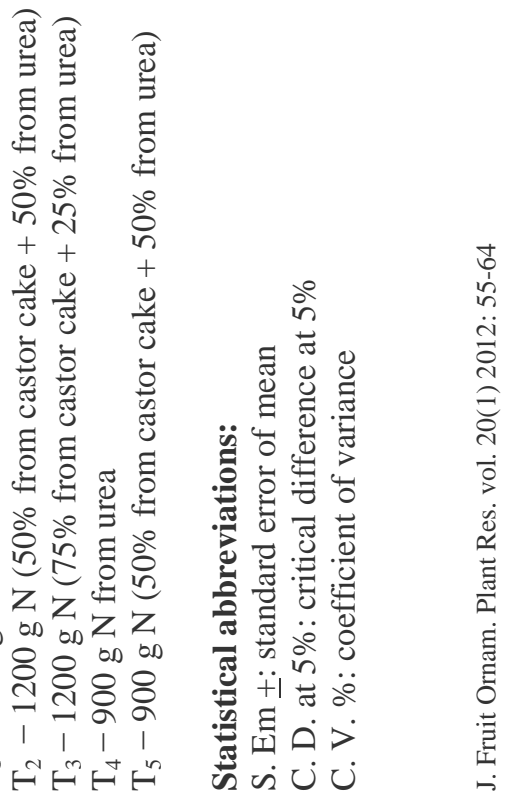




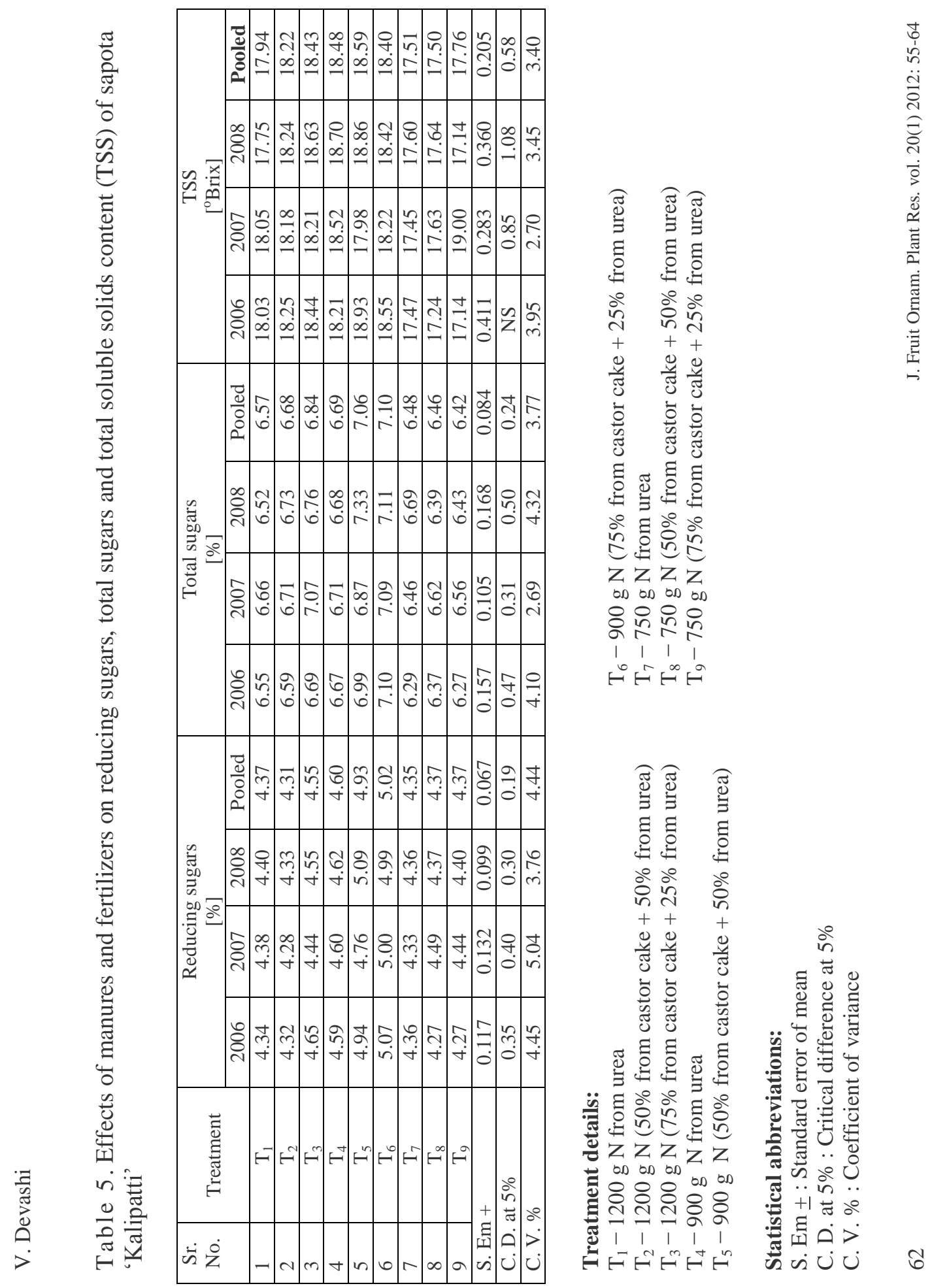


application of organic manure (castor cake) in combination with inorganic fertilizers. This might have been due to a gradual and steady release of nutrients during the growth period. The castor cake as an organic source of nitrogen improved the soil's physical condition, microbial activities in the soil and supplied some micronutrients. This could be attributed to a higher $\mathrm{C} / \mathrm{N}$ ratio which led to increased synthesis of carbohydrates and increased plant metabolism. Similar results were also obtained by Durrani et al. (1982b), Bhuva et al. (1990), Singh et al. (2000), Boora and Singh (2000), Boora et al. (2002) and Singh et al. (2003).

\section{CONCLUSION}

From the preceding discussion, it is concluded that the application of $900 \mathrm{~g}$ $\mathrm{N}$ per tree per year in the form of urea or $900 \mathrm{~g} \mathrm{~N}$ per tree per year where $50 \%$ $\mathrm{N}$ is in the form of urea and $50 \% \mathrm{~N}$ in the form of castor cake should be applied to fruit bearing sapota trees for optimal tree growth, high yield and good quality fruit.

\section{REFERENCES}

Bhuva H.P., Katrodia J.S., Patel R.G. 1990. Effect of different levels of moisture regime and nutrient on growth, yield and economics of sapota (Achras sapota L.[Manilkara zapota]) cv. Kalipatti. HARYANA J. HORTIC. SCI. 19(1-2): 71-78.

Boora R.S., Singh D. 2000. Effect of NPK on growth, yield and quality of sapota (Manilkara achras (Mill.) Fosberg) cv. Cricket Ball. HARYANA J. HORTIC. SCI. 29(3/4): 188-189.

Boora R.S., Singh D., Siddiqui S., Verma S.L. 2002. Response of sapota to NPK fertilization. HARYANA J. HORTIC. SCI. 31(1/2): 15-17.

Dubois M., Gilles K., Hamilton J. 1956. Colorimetric method for determination of sugars and related substances. ANAL. CHEM. 28: 350-356.

Durrani S.M., Patil V.K., Kadam B.A., Khedkar D.M. 1982a. Effect of N, P and $\mathrm{K}$ on the physico-chemical characteristics of sapota (Achras zapota Linn.). J. FOOD SCI. TECHNOL. 19(4): 164-165.

Durrani S.M., Patil V.K., Kadam B.A. 1982b. Effect of N, P and K on growth, yield, fruit quality and leaf composition of sapota. INDIAN J. AGRIL. SCI. 52 (4): 231-234.

Hodge J.E., Hofreiter B.T. 1962. Determination of reducing sugars and carbohydrates. In: Whistler R.L., Wolfrom M.L., (eds.), Methods in carbohydrate chemistry, Vol. 1 Academic Press, London, pp. 380-394.

Panse V.G., Sukhatme P.V. 1985. Statistical methods for Agricultural workers, Publication and Information Division, ICAR, New Delhi, pp. 157-167.

Singh R., Singh D., Ram T. 2000. Studies on the effect of NPK on growth, yield and quality of sapota (Manilkara achras (Mill.) Fosberg) cv. Cricket ball. ANNALS BIOLOGY 16 (1): 79-82.

Singh D., Ahlawat V.P., Verma S.L., Singh B. 2003. Nitrogen, phosphorus and potassium fertilization in 'Cricket Ball' sapota (Manilkara achras). INDIAN J. AGRIL. SCI. 73(8): 419-421.

Sulladmath U.V., Reddy M.A. 2001. Fruit: Tropical and Sub Tropical, Vol. 2, pp. 329-360.

Warade S.D., Desale S.B., Shinde K.G. 1995. Effect of organic and inorganic and biofertilizer on yield of onion bulb. J. MAHARASHTRA AGRI. UNI. 20: 467-468. 


\title{
WPEYW AZOTU ORGANICZNEGO \\ I NIEORGANICZNEGO NA WZROST, PLONOWANIE I JAKOŚĆ OWOCÓW SĄCZYŃCA ODMIANY KALIPATTI
}

\author{
Varu Devashi
}

S T R E S Z C Z E N I E

Celem doświadczenia było zbadanie wpływu azotu organicznego i nieorganicznego w postaci mocznika i wytłoków rycynowych na wzrost, plonowanie i jakość owoców sączyńca. Azot w formie mocznika istotne wpłynął na wzrost wegetatywny drzew. Największą wysokość drzew $(7,26 \mathrm{~m})$, rozpiętość drzew $(8,11 \mathrm{~m}$ w kierunku $\mathrm{N}-\mathrm{S}$ i 8,13 m w kierunku E-W), masę owoców (63,65 g), liczbę owoców na drzewo $(2627,56)$ i plon owoców na drzewo $(163.30 \mathrm{~kg})$ otrzymano przy nawożeniu dawką $900 \mathrm{~g} \mathrm{~N} /$ drzewo w postaci mocznika. Podobne wyniki uzyskano przy nawożeniu taką samą dawką azotu, w której $50 \% \mathrm{~N}$ pochodziło z mocznika a $50 \% \mathrm{~N}$ z wytłoków rycynowych. Najwyższą zawartość cukrów ogółem i cukrów redukujących w owocach stwierdzono po zastosowaniu dawki $900 \mathrm{~g}$ N/drzewo, w której 25\% N pochodziło z mocznika a $75 \%$ z wytłoków rycynowych.

Słowa kluczowe: nawożenie, mocznik, azot, wytłoki rycynowe 